\title{
OBITUARY
}

\section{DAVID JAMES GIBB WISHART}

Dr. WISHART like so many of our most distinguished medical confrères was a son of the Manse. He was, on both sides, of Scottish parentage and was born in Canada in 1859 . In addition to a number of British diplomas he received in I9I3 the Fellowship of the American College of Surgeons. He was also a Fellow of the American Laryngological Society and of the Laryngological, Rhinological and Otological Society. In Canada he held important professorships and other appointments.

The appreciation which he received at home and on both sides of the St. Lawrence was amply justified by his personal as well as his professional qualities.

All the years of his practice were spent in Toronto where he was continuously a teacher and practitioner of Oto-Laryngology, and at the time of his death in December, I934, held the status of Emeritus Professor of Oto-Laryngology University of Toronto, late Chief of Service Otology, Rhinology and Laryngology Toronto General Hospital, Consultant in Oto-Laryngology Toronto General Hospital and Hospital for Sick Children. In the War he held the rank of Lieut-Colonel and Consultant in his specialty.

He was a deeply religious man and carried his religion into his daily life, without, however, losing a quiet but cheerful sense of humour which with his sterling qualities of character gained for him the affection and respect of his household and his many friends. His hospitality was generous, a source of pleasure to his guests, and a joy to himself. Those who attended the Meeting of the British Medical Association in Toronto many years ago will heartily endorse this opinion. Those who shared his companionship testify to his keen interest in sports and his fondness for outdoor life. He was sound in play as well as in work and had a thoroughly good influence on those who knew him and who would have been glad to have known more of him.

James Dundas-Grant. 